\title{
Regnskabsmetoden i Berthe Marie Alexandersens ugebog
}

Af Bodil Tornehane.

I skuffen i et knipleskrin, der nu befinder sig pa Haderslev Amls Museum, ligger der en lille, hjemmegjort bog, der viser sig at indeholde en kniplerskes reginskab over, hyor meget hun har naet at kniple i de godt 2 ar og 1 maneder, bogen er fort.

Ebba Busch har i den foregáende arlikel "Fra en kniplerskes ugebog" (som der i det folgende henvises til ved belegnelsen E. B.) gjort rede for kniplerskens forhold, og hvad bogen viser om hendes arbejdsprastation. I denne artikel skal undersoges, hvad ugebogen fortæller om hendes regnemetode og regnesikkerlied.

Berthe Marie Alexandersen har hver aften, nar knipleskrinet hlev sat til side efter dagens arbejde, med blyant skrevet et tal ind i bogen, nemlig det antal "takker" (hele tunger), hun har lavet den dag. Det er de tal, vi ser yderst til venstre pá bogens linier (E.l3. fig. 2). Hver af disse talrækker lader sig nemlig opdele i syv enkeltal, der maximalt er pá 18; det er det hojeste antal takker, hun overhovedet nar at kniple på en enkelt dag, og det er kun fa dage midt i den lyse sommerlid. hun overkommer sá meget. Om sondagen har hun taget blækhus og pen frem. De syv daglige opgivelser er omhyggeligt blevet trukket op og afsluttet med en prik. Sâ folger et antal alen og takker, det er en angivelse af den samlede langde, hun har kniplet siden sidste ugeopgorelse. Resten af linien på bogens venstre side er udfyldt med en datering, der ikke blot giver datoen, men også hvilken sonday i kirkearet, det drejer sig om.

Linien fortsætter pâ højre side med et andet regnskab, der øjensynlig holder rede på, hvor meget hun har lavet ialt af sin knipling, siden hun satte den op. Bogen starter med at overføre 
1228 alen og 17 takker fra en tidligere regnskabsbog, der nu er væk, og slutter brat lidt ind i en uge, antagelig på grund af sygdom, der har forhindret hende $i$ atter at genoptage kniplearbejdet. Formen i dette fortsatte regnskab er ejendommelig, idet vi på linien først ser en række angivelser af de hele antal alen, hun passerer, og ved det sidste alental er tilføjet et antal takker - sá langt er hun altså den dato ialt nået med sin knipling. Linien slutter med en fuld gentagelse af dateringen fra ugeregnskabet på venstre side. Bogen indeholder således ialt tre regnskaber, en daglig opgørelse, en ugeopgørelse samt et fortsat regnskab.

Formen i det sidste tillader os at slutte noget om, hvordan hendes regnskabsmetoder har været. Anførelsen af hvert helt alental, hun passerer, røber, at der er tale om en fortsat optælling, der genoptages uge efter uge, og ikke om en sammenlægning af tallet fra sidste uges fortsatte regnskab med den forløbne uges arbejdspræstation. Hendes regnefærdighed har sikkert ikke været så stor, så hun har mestret den vanskelige opgave at lægge sådanne to angivelser sammen og foretage omregningen fra takker til alen (der går 27 af hendes takker på en alen). Men hun har kunnet tælle, og hun har, som så mange før hende, kunnet klare sit regnskab på denne primitive måde. Metoden er den samme, vi møder den dag idag, når vi f. eks. tæller forbikørende biler og sætter en streg for hver vogn, der passerer, og tegner hver femte streg skråt ned over de foregående fire. Det er også samme metode, vi indtil for ikke så længe siden kunne møde ved regnskabsførelse ved et kortspil som »brus"; her tegnede man en 》redekam «, en lodret streg med ti vandrette streger ud fra, ved hvert point stog man en streg «, satte en lille tværstreg over en af de vandrette streger, og fortsatte med dette i lodret retning, så man havde fået 10 point, hver gang man havde en lodret række afkrydsninger på "redekammen ". I dag bruger man gerne tændstikker i stedet. Regning på "redekam" med 12 eller 20 stænder" egner sig fortrinligt til optælling i dusin eller snese. Regnemetoden er iøvrigt den samme som den, vi møder ved regning på »abacus «, kugleramme.

At regnskaberne på de to sider af bogen er ført uafhængigt, og ikke er et »dobbelt bogholderi « for kontrollens skyld, viser de mange uoverensstemmelser, der er imellem de tre regnskaber. 


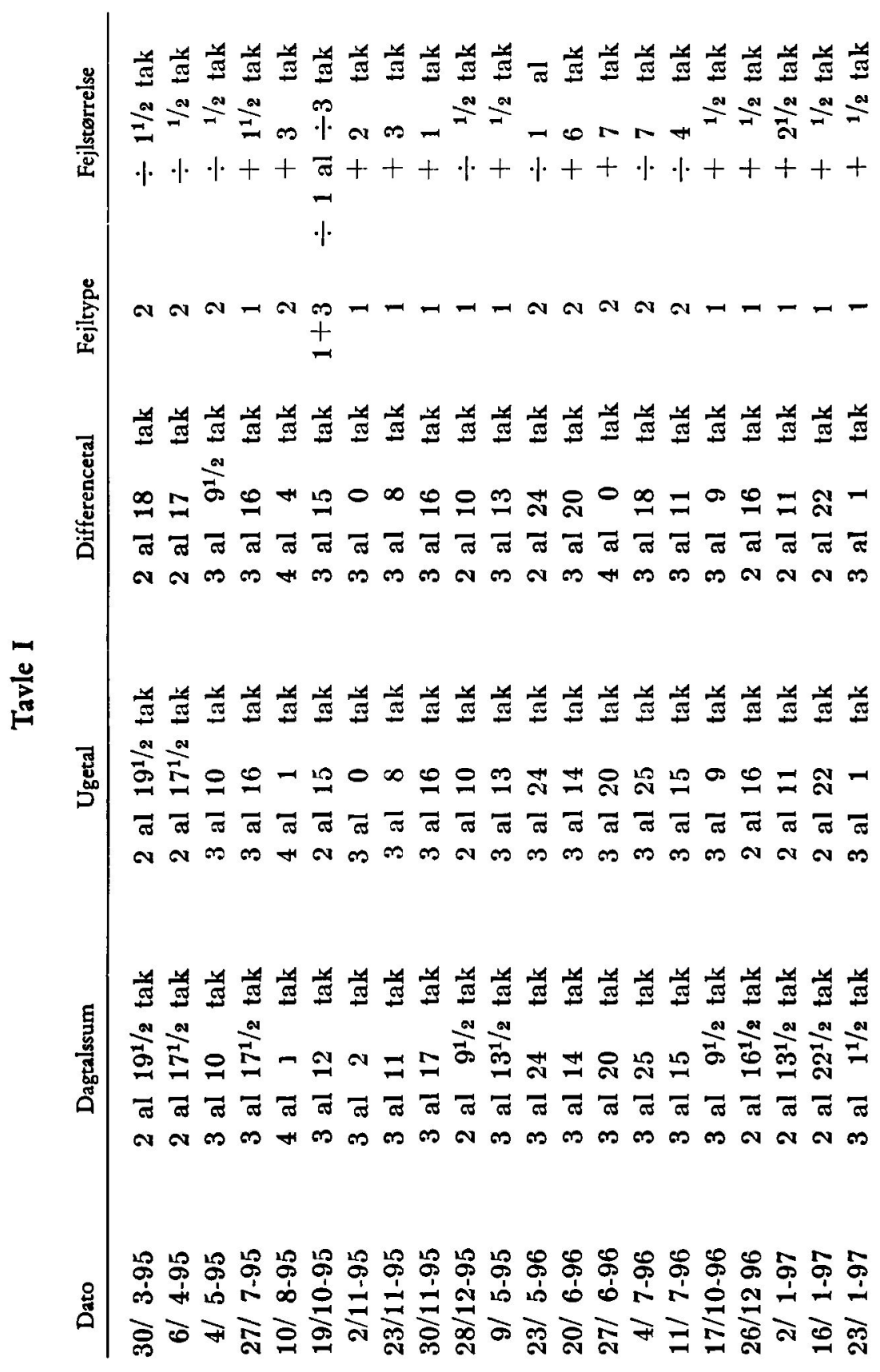


Hele bogen er blevet underkastet en kontrolregning, idet der for hver uge er foretaget en sammenlægning af ugens syv daglige tal, omregnet til alen og takker. Dette tal, som vi kan benævne »dagtalssummen «, er så sammenlignet dels med ugeregnskabets opgivelse, fremover kaldet 》ugetallet ", dels med differencen mellem vedkommende uges fortsatte regnskab og foregående uges, 》differencetallet ". I 21 tilfælde finder vi uoverensstemmelser mellem disse tal, dette talmateriale er gengivet $i$ tavle 1 . Kun een gang, $19 / 10$ 1895, finder vi uoverensstemmelse mellem alle tre tal, 11 gange er der uoverensstemmelse mellem dagtalssummen og de ovrige (fejl af type 1), 9 gange mellem differencetallet og de to ovrige (fejl af type 2).

Fejl af type 2 svarer til et korrekt dag- og ugeregnskab, men forkert optælling i det fortløbende regnskab. Der er grund til at hæf te sig ved tallene fra $23 / 51896$, idet af vigelsen her ligger i optællingen af de hele alen og ikke i takkerne, som det ellers er tilfældet. Hun har utvivlsomt sat en nål i kniplingen ved det hele alental og flyttet denne nål, hver gang hun har optalt 27 takker, og derefter grebet til pennen for at notere det nye hele alental i ugebogen. Denne ene gang har hun glemt at notere ved en af optællingerne, hun er nok blevet distraheret i sit arbejde. De øvrige fejl af type 2 er småfejl $i$ optællingen af takkerne.

Ved fejl af type 1 afviger dagtalssummen fra de to øvrige tal. Da alt, som det ovenfor er fremhævet, tyder på, at kniplersken har talt sig frem, ser det ud til, at disse fejl skyldes forkerte opgørelser af det daglige antal kniplede takker, og at ugetallet er opstået ved en selvstændig optælling ud fra et mærke, sat i kniplingen sidste søndag, og ikke ved en addering og omregning til alen og takker af de syv dagtal.

At det forholder sig sådan, bekræftes ved en analyse af tallene fra 19/10 1895, hvor de tre opgivelser alle afviger indbyrdes. Her er det påfaldende, at medens dagtalssummen blot er 3 takker mindre end differencetallet, er dette igen præcis 1 alen større end ugetallet. Her drejer det sig åbenbart atter om en forglemmelse af markering af et optalt alental (her noterer hun ikke i bogen, hver gang hun har optalt en hel alen; men da det er tal, der højst er 4, kan hun f. eks. have markeret det ved at sætte nåle $i$ puden). Benævner vi optællingsfejl $i$ ugetallet som fejl af type 3, 
er der i denne uge tale om en overlejring af fejl af typerne $1 \mathrm{og}$ 3. Vi må konstatere en meget stor sikkerhed ved hendes optællinger af ugens samlede arbejde; når det kniber mere $i$ det fortsatte regnskab, skyldes det nok de større tal og den mere komplicerede fremgangsmåde med at skulle gribe til pen og blæk for at indføre et tal i bogen, hver gang en alen er optalt.

At der optræder så mange småfejl i de daglige opgivelser, tyder på mangelfuld markering af, hvor langt hun var kommet foregående dag. For at forstå dette forhold må vi betragte den måde, de sønderjyske kniplersker arbejdede på, nærnere. Som vi ser i E.B. fig. 1, sidder der på hendes skrin et prikbrev af begrænset længde, det spænder over 11 takker. Nâr hun er nået så langt, som prikbrevet tillader, må hun sætte om, d.v.s. binde pindene ind, tage alle nåle ud og forsigtigt løfte knipling og pinde op, så det sidste mønster, hun har kniplet, nu dækker over prikbrevets øverste mønsterdel, hvor nålene atter sættes gennem kniplingens slag ned i de tilsvarende huller i mønsteret. Hun kan så atter kniple ned langs prikbrevet til dets ende - ialt 10 takker. Dette forhold har sikkert været benyttet til den daglige opgørelse, idet hun blot har skullet mærke sig, hvor mange takker, der var igen på prikbrevet ved starten, evt. omsætninger i dagens løb, samt hvor langt hun var nået ned på prikbrevet efter endt dagsarbejde. Har hun arbejdet på denne måde, forklarer det, at der let har kunnet indsnige sig fejl $\mathrm{i}$ de daglige opgivelser. Disse fejl får imidlertid ingen indflydelse på ugeopgørelsen, når hun undlader at regne de syv dagtal sammen og $i$ stedet tæller sig frem til ugens arbejde ud fra et mærke (en nål), sat $i$ kniplingen ved forrige ugeopgørelse.

Den totale mangel på angivelse af, hvornår der er blevet sskåret af «, endsige et regnskab over, hvor meget hendes betaling for det leverede arbejde har været, er påfaldende. Regnskabet har åbenbart ikke haft til formål at kontrollere kniplingshandlerens opmåling af det stykke, der blev sskåret af «. Dette kan forklare et specielt forhold, nemlig at kniplersken synes at have arbejdet med en alen, der er kortere end den officielle. ${ }^{1}$ Alt tyder på, at den knipling, der sidder på knipleskrinet, er den, hun arbejdede på i de mange år - ikke mindst det utroligt slidte prikbrev, som kun den, der havde arbejdet med vedkommende monster $\mathbf{i}$ årevis, 
kunne få en så velformet knipling ud af, som den, der sidder på skrinet. Nu følger det af ugebogen, at der gik 27 takker på en alen, altså at en tak skulle være på ca. $23 \mathrm{~mm}$, medens prikbrevets knipling kun har ca. $19 \mathrm{~mm}$ pr. tak. Vi må åbenbart reducere alle hendes opgivelser med en faktor $19 / 23$ for at få de virkelige mål frem. Specielt må vi bemærke, at de 1623 alen og 12 takker, hun er nået op på ved ugebogens afbrydelse, ikke bliver til $1019 \mathrm{~m}$., som den officielle omregning fra alen til meter ville give, men $842 \mathrm{~m}$., stadig en imponerende længde.

Den nøje gennemgang af ugebogens talmateriale bringer os tæt ind på Berthe Marie Alexandersen og hendes arbejdsmetode. Det er utroligt, hvor meget de tørre talrækker afslører om den kniplerske, der førte dem ind i sin ugebog.

\section{NOTE}

1. Omregningen er foretaget efter den sjællandske alen $=62,77 \mathrm{~cm}$. Også selvom man omsætter efter den lybske alen $=$ ca. $57 \mathrm{~cm}$ eller den specielle tonderske $=$ ca. $59 \mathrm{~cm}$ (jfr. Maal og Vægt, red. af Svend Aakjær, Nord. Kultur Bd. XXX, 1936) er den af Berthe Marie Alexandersen anvendte alen for kort. 